\title{
СРАВНЕНИЕ ТЕРМИЧЕСКИХ СВОЙСТВ ЦЕЛЛЮЛОЗНЫХ ВОЛОКОН МЕТОДОМ ПИРОЛИЗНОЙ ГАЗОВОИ ХРОМАТОГРАФИИ
}

O. KIRRET, Aili KOGERMAN. TSELLULOOSIKIUDUDE TERMILISTE OMADUSTE VORDLEMINE POROLUUSGAASIKROMATOGRAAFIA MEETODIL

o. KIRRET, Aili KOGERMAN. COMPARISON OF THE QUALITY OF CELlULOSE FIBRES BY PYROLYSIS GAS CHROMATOGRAPHY

Среди большого количества природных и химических целлюлозных волокон наибольшее распространение получили хлопчатобумажные, льняные и вискозные волокна. Основным составным компонентом природных целлюлозных волокон является целлюлоза, а сопутствующими различные высокомолекулярные (протеины, гемицеллюлоза) и низкомолекулярные (жиры, минеральные соли, вода) примеси, количество и состав которых влияют на физические и химические свойства волокон, в частности на их термостойкость. Содержание целлюлозы в природных волокнах колеблется в широком диапазоне - от $80-90 \%$ в хлопкесырце и льне до $99 \%$ в интенсивно отбеленном льне. В процессе отбелки из волокна удаляются такие примеси, как протеины, белки, пектины, лигнин. При этом существует опасность разрушения микроструктуры волокна (т. н. букета клеток), а значит, и снижения его качества. Поэтому в промышленных условиях за режимом отбелки должен быть обеспечен строгий контроль.

Среди методов изучения термических свойств материалов метод пиролизной газовой хроматографии занимает особое место, так как он позволяет определять и тонкие различия в кристаллической структуре вискозной кордной нити [1], а также влияние микроколичеств солей железа и марганца на термическую стабильность целлюлозы $\left[{ }^{2}\right]$.

В данной работе изучалось влияние отбелки на термические свойства хлопчатобумажного и льняного волокна. Образцы льна получены от Пярнуского льнокомбината, хлопчатобумажное волокно - из НИИ химии и технологии хлопковой целлюлозы (Ташкент). Методом ступенчатой пиролизной газовой хроматографии изучали температурные зависимости выходов $\mathrm{H}_{2} \mathrm{O}, \mathrm{CO}$ и $\mathrm{CO}_{2}$ при пиролизе образцов [3], т. е. определяли скорости дегидратации, декарбоксилирования и декарбонизации в зависимости от природы целлюлозного волокна и от его предыстории.

Методика: навеску образца 2-3 мг, взвешенную в кварцевую трубочку, нагревали в пиролизаторе в области температур от 100 до $500^{\circ} \mathrm{C}$, ступенчато поднимая температуру на $10^{\circ} \mathrm{C}$ через 15 с. После каждого нагрева образца продукты пиролиза переводили в колонку хроматографа и определяли количественный выход $\mathrm{H}_{2} \mathrm{O}, \mathrm{CO}$ и $\mathrm{CO}_{2}$. Колонка: длина 2,4 м, диаметр 0,6 мм, заполнена Сепароном-CHN, температура $80^{\circ} \mathrm{C}$, скорость газа-носителя гелия 50 мл/мин, хроматограф «Хром-5».

Сравнивая скорости выделения при пиролизе $\mathrm{H}_{2} \mathrm{O}, \mathrm{CO}$ и $\mathrm{CO}_{2}$ (рисунок), можно видеть, что термические свойства натурального льна значительно отличаются от термических свойств хлопчатобумажного и вискозного волокна. У льна температурный максимум дегидратации и также выделения при пиролизе $\mathrm{CO}$ и $\mathrm{CO}_{2}$ повышается на $20^{\circ} \mathrm{C}$. 

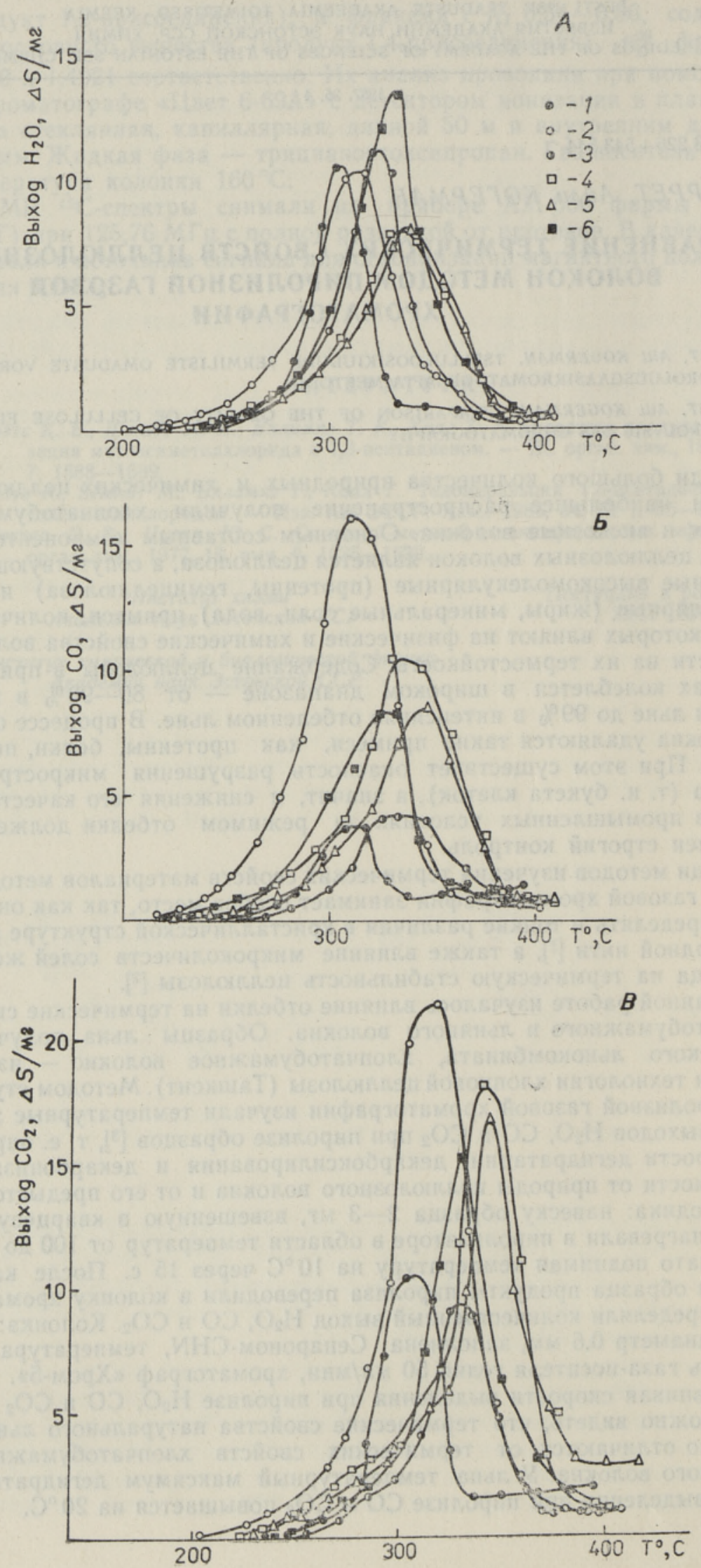
Необходимо указать и на то, что если отбелка (при правильно выбранном режиме) хлопчатобумажного волокна приводит к повышению его термостабильности (температуры максимальных выходов всех продуктов пиролиза повышаются на $10^{\circ} \mathrm{C}$ ), то отбелка льняного волокна хлорсодержащими препаратами приводит к обратному эффекту: температуры выделения при пиролизе $\mathrm{H}_{2} \mathrm{O}, \mathrm{CO}, \mathrm{CO}_{2}$ снижаются примерно на ту же величину и несколько повышается количество пиролизной воды (таблица).

Выходы легких продуктов при пиролизе разных целлюлозных волокон

\begin{tabular}{|c|c|c|c|c|c|c|}
\hline \multirow[b]{2}{*}{ Волокно } & \multicolumn{2}{|c|}{$\mathrm{H}_{2} \mathrm{O}$} & \multicolumn{2}{|c|}{$\mathrm{CO}_{2}$} & \multicolumn{2}{|c|}{$\mathrm{CO}$} \\
\hline & $\mathrm{MKr} / \mathrm{Mr}$ & $T_{\text {маке }},{ }^{\circ} \mathrm{C}$ & $\mathrm{MKr} / \mathrm{Mr}$ & $T_{\text {мake }},{ }^{\circ} \mathrm{C}$ & $\mathrm{MKr} / \mathrm{Mr}$ & $T_{\text {маке }},{ }^{\circ} \mathrm{C}$ \\
\hline Вискозное волокно & 132 & 305 & 81 & 310 & 27 & 310 \\
\hline Хлопок-сырец & 177 & 315 & 124 & 315 & 108 & 315 \\
\hline $\begin{array}{l}\text { Хлопок отбелен- } \\
\text { вый }\end{array}$ & 119 & 324 & 83 & 328 & 28 & 340 \\
\hline $\begin{array}{l}\text { Эстонский неотбе- } \\
\text { ленный лен }\end{array}$ & 147 & 335 & 165 & 345 & 72 & 340 \\
\hline $\begin{array}{l}\text { Белорусский неот- } \\
\text { беленный лен }\end{array}$ & 142 & 340 & 136 & 348 & 57 & 350 \\
\hline $\begin{array}{l}\text { Эстонский отбе- } \\
\text { ленный лен }\end{array}$ & 168 & 325 & 159 & 335 & 62 & 330 \\
\hline
\end{tabular}

Эти данные указывают на переокисление исследуемого нами образца льна из-за неправильно выбранного режима отбеливания. При переокислении льна происходит разрушение микроструктуры волокна, а также снижается степень полимеризации целлюлозы, что в свою очередь приводит к снижению не только термических, но и механических и потребительских свойств льна.

До 1940 г. в Эстонии производилось до 6 тыс. т высококачественного льна, лен служил одной из статей экспорта, давая приличные деньги. Теперь же его производство упало до 1,5 тыс. т в год, тысячелетние традиции выращивания и переработки этого благородного, ничем не заменимого природного волокна во многом утрачены. Но эти традиции требуют возрождения, так как спрос на тонкое льняное волокно растет всюду.

Наши исследования термических свойств случайно выбранных образцов целлюлозных волокон не претендуют на оценку качества производимых на Пярнуском льнокомбинате льняных материалов. Тем не менее они указывают на необходимость строгого контроля за режимом отбелки льна. Несоблюдение этого режима может привести к порче тонкой структуры волокна.

С другой стороны, приведенные данные вновь подтвердили широкие возможности метода пиролизной газовой хроматографии для изучения свойств целлюлозных волокон.

Температурная зависимость выхода $\mathrm{H}_{2} \mathrm{O}$ (А), $\mathrm{CO}$ (Б) и $\mathrm{CO}_{2}$ (В) при пиролизе вискозы $(1)$, хлопка-сырца (2), отбеленного хлопчатобумажного волокна $(3)$, эстонского неотбеленного льна (4), белорусского неотбеленного льна $(5)$ и эстонского отбеленного льна $(6)$. 
1. Kogerman, A., Heinsoo, E., Kirret, O., Shevchenko, A. Investigation of the effect of catalytic activity of ferrous salts on thermal stability of cellulose by stepwise pyrolysis gas chromatography. - In: 27th IUPAC Congress, August 27-31, 1979. Helsinki, 1979, 425.

2. Kogerman, A., Heinsoo, E., Sevčenko, A., Bokova, S., Kirret, O. Ober die Einwirkung von Eisen(II) - und Mangan(II)-Salzen auf den thermischen Abbau der Cellulose. - Acta Polym., 1985, 36, N 3, 172-176.

3. Heinsoo, E., Kogerman, A., Kirret, O., Coupek, J., Vilkova, S. Stepwise pyrolysis-gas chromatography of viscose fibres. - J. Anal. Appl. Pyrol., 1980, 2, N 2, 131-139.
Ннститут химии
Академии наук Эстонской ССР
Поступила в редакцию
12/V 1987

\section{EESTI NSV TEADUSTE AKADEEMIAS}

\section{EESTI NSV TEADUSTE AKADEEMIA 41. AASTAKOOSOLEK}

25. märtsil 1987 toimus Eesti NSV Teaduste Akadeemia üldkogu 41. aastakoosolek, mille päevakorrast keskse osa moodustasid akadeemia presidendi K. Rebase avasõna ning osakondade akadeemiksekretäride ja presiidiumi teadusliku peasekretäri ülevaated 1986. aasta tegevusest ja eelseisvatest ülesannetest. Ohiskonnateaduste Osakonna tööst kõneles akadeemiksekretär Juhan $\mathrm{K}$ a h k, Informaatika ja Tehnilise Füüsika Osakonna tulemustest akadeemiksekretär Enn Tõ ugu, Keemia-, Geoloogia- ja Bioloogiateaduste Osakonna tegevusest akadeemiksekretäri kt. Helle Si m m ning Füüsika ja Astronoomia Osakonna saavutustest akadeemiksekretäri kt. Vladimir $\mathrm{Hi}$ ž n jakov.

Ettekandega akadeemia presiidiumi tegevusest 1986. aastal ja perspektiivülesannetest esines Eesti NSV Teaduste Akadeemia presiidiumi teaduslik peasekretär Raimund $\mathrm{H}$ a g e $\mathrm{lb}$ erg.

Ettekandele järgnenud läbirääkimistel võtsid sōna Füüsika Instituudi direktor Peeter S a a ri, Keele ja Kirjanduse Instituudi direktor Endel Sõ g e l, Eksperimentaalbioloogia Instituudi direktor Oskar Priilinn, Zooloogia ja Botaanika Instituudi direktor Erast $\mathrm{P}$ a r m a s to, Tartu Riikliku Olikooli kateedrijuhataja Hans Trass, Keemilise ja Bioloogilise Füüsika Instituudi direktor Endel L i p p$\mathrm{m}$ a a, Tallinna Polütehnilise Instituudi kateedrijuhataja Mihkel Veiderma, korrespondentliige Eduard Päll, Ajaloo Instituudi sektorijuhataja Karl S i i livask, Geoloogia Instituudi direktor Dimitri Ka l jo ja Eesti NSV Teaduste Akadeemia asepresident Arno Köörna.

Koosolekust osavôtjad austasid leinaseisakuga kaht meie hulgast lahkunud akadeemia asutajaliiget. 7. septembril 1986 varises manalasse mehaanikateadlane, Eesti NSV Teaduste Akadeemia akadeemik Leo Jürgens on. 16. detsembril 1986 suri Eesti NSV teeneline teadlane, Eesti NSV Teaduste Akadeemia akadeemik bioloogiadoktor professor Harald $\mathrm{Ha}$ berm a n.

1987. aasta üliōpilaspreemia anti välja ühiskonnateaduste alal. Parima teoreetilise töö eest sai preemia Keele ja Kirjanduse Instituudi aspirant Toomas $\mathrm{Hel}$. Tema uurimus kƯks võimalus morfoloogia käsitlemiseks» valmis TRU-s dotsent Reet Kasiku juhendusel. Parima rakendusliku töö autor oli EPA üliōpilane Helgi Li i v, kelle teema oli $\star$ NSV Liidu majandusliku ja sotsiaalse arengu kiirendusprogramms (juhendaja professor Herbert Metsa).

Aastakoosolekust võttis osa 16 akadeemikut 20-st ja 23 korrespondentliiget 29-st. Külaliste hulgas olid Eesti NSV Ministrite Nõukogu esimehe esimene asetäitja Indrek T o o m e, EKP Keskkomitee teaduse ja õppeasutuste osakonna juhataja Aili A be n, Eesti NSV Olemnōukogu Presiidiumi esimehe asetäitja Maia Leosk, EKP Tallinna Linnakomitee sekretär Ahto Vella m a a, Eesti NSV körg- ja keskerihariduse minister Väino $\mathrm{R}$ a j a n g u, EKP Keskkomitee teaduse ja oppeasutuste osakonna juhataja asetäitja Vello $\mathrm{Ni}$ i no ja ja EKP Tallinna Linnakomitee teaduse ja õppeasutuste osakonna juhataja Annela Laht.

Uksikasjalikum ülevaade aastakoosolekust ja vastuvõetud otsus on avaldatud «Toimetiste» ühiskonnateadusteseeria 1987. aasta 4. numbris ning bioloogia- ja füüsika-matemaatikaseeria 1988. aasta 1. numbris. 